Pre-Print Draft

Journal of Islamic Marketing, 2012

\title{
Islamic Marketing: Insights from a Critical Perspective
}

\author{
Aliakbar Jafari \\ Department of Marketing, \\ University of Strathclyde, UK
}

\begin{abstract}
This paper seeks to encourage a critical dialogue within the realm of Journal of Islamic Marketing. It invites marketing scholars and practitioners working on various topics related to Islam and Muslim societies to adopt fresh theoretical and methodological positions that would enhance our understanding of multiple marketing and market dynamics in Muslim societies. The author suggests that the advancement of knowledge in the area of Islamic marketing requires reflexivity and self-critique. The paper highlights the constructive value of critical approach to the development of marketing theory and practice. This paper reflects the author's personal viewpoint on the production of knowledge and improving practice in the realm of Islamic marketing.
\end{abstract}

Keywords: Islam, Islamic marketing, Marketing, Markets, Critical perspective, Orientalism, Self-Orientalism

\section{Introduction}

The idea of writing this manuscript emerged from a meeting I had with Dr. Bakr Ahmed Alserhan (the Editor of Journal of Islamic Marketing) in the United Arab Emirates University in Alain. The purpose of my visit was to discuss the progress of Journal of Islamic Marketing (JIMA). Amongst my key questions were: why start JIMA? Why now? What is meant by Islamic marketing? What are the boundaries of Islamic marketing? Can the Journal accommodate critical perspectives? Is JIMA part of the project of Islamisation of knowledge? Due to space constraints, I do not intend to explain the details of our long discussion in this short article. I would like to expand on these topics in sufficient depth (as they deserve) on another occasion. Here, I stick only to one point which was central to our conversation: the importance of reflexivity and self-critique to the advancement of knowledge in the realm of Islamic marketing.

Our meeting was more fruitful than I had expected. I should confess that before talking to Dr. Alserhan, I was somehow sceptical of the launch of JIMA as I thought it would further widen the gap between Islam and the rest of the world. JIMA, I thought, would not 
only not help inter-cultural understanding and communication amongst scholars and practitioners of marketing, but also further intensify the institutionalisation of binary oppositions of Islam versus the West or the non-Islamic world. Bakr's opinion, on the contrary, was that JIMA was intended to bridge the gap between scholars and practitioners in different parts of the world and enhance an understanding of various marketing dynamics and phenomena in the Muslim world. This is what I truly hope will happen. A key viewpoint that Bakr and I shared was that achieving this objective relies on the degree of commitment of authors who wish to publish in JIMA to reflexivity and self-critique in their knowledge production quest, with a view to ultimately contributing to marketing theory in general.

As outlined in the editorial objectives of JIMA (available on the Emerald website), the Journal covers a wide range of exciting issues related to marketing theory and practice. The ultimate objective of JIMA, just like any other marketing journal, should therefore be to enhance theory in different areas of scholarship within the general framework of marketing. Parallel to this, marketing practitioners can both contribute to and benefit from this intellectual dialogue. A key point to bear in mind is that the purpose of the Journal is not to study Islam or the Muslim world as such, but to study different marketing phenomena in relation to Islamic principles and practices, or within the context of Muslim societies. This means that adding the term 'Islamic' to a context will not, in any way, make that context worthy of consideration for publication in JIMA unless the analysis of a particular phenomenon (or set of phenomena) will eventually add to our existing knowledge of markets and marketing theory.

After a year of publication, it is refreshing to see that a variety of interesting topics have been addressed in the Journal. However, whilst there are many high quality articles that make considerable contributions to the field, there are also a number of drawbacks that need to be adequately addressed in the Journal. In my view, these weaknesses are generally related to the following overarching issues: 1) the way 'Islam' and 'Islamic societies' are conceptualised is problematic 2) there is a reductionist approach to both Islam and marketing 3) generally, a critical discourse is missing from the articles published in the Journal.

Of course, every journal needs some time to be able to establish itself in a disciplinary arena and position itself as a scholarly outlet with a unique value proposition. The newly founded JIMA is not therefore an exception. I acknowledge the fact that for researchers working on various marketing phenomena related to Islam or Muslim societies, it will take a while to start to challenge the existing theories, models, and practices and enhance our existing knowledge of markets and marketing. Yet, in my opinion, what JIMA urgently needs at its early stage of development is constructive critique. I am indebted to Bakr for providing me with this opportunity to share some of my critical viewpoints with my fellow scholars. I hope that my colleagues will continue this critical dialogue. It is only through ongoing critique that we will be able to grow intellectually and collectively contribute to the development of marketing theory and improvement of marketing practice in the context of Islamic societies.

Based on my critical reading of past articles published in JIMA, in the present manuscript I set forth my discussions around three key points. Firstly, I will argue why Islamic marketing should avoid the disastrous trap of Orientalism. We need to rethink our conceptualisation of 'Islam' and 'Islamic societies' with a fresh sight. Many areas of humanities and social sciences in the Muslim world are barely capable of breaking out of the cocoon of defining their own theoretical and philosophical fundamentals with reference to the 
'theoretical structures' that are constructed by Western philosophy as a set of ideas, beliefs, and practices (Said, 1978). Secondly, I will highlight the dangers of reductionism and oversimplification of Islam as a 'marketing tool' as either reported or implied in some of the JIMA articles. Thirdly, I will argue why Islamic marketing scholars should distance themselves from sacralising Islam. Sacralisation of Islam will inevitably reduce tolerance and hamper the acceptance and growth of critique. Islam, by default, will continue to remain a divine source of guidance for mankind and does not need any apology. Our task, as researchers, is not to defend Islam, but to analyse how Muslims' interpretations of, and beliefs in, Islam affect their everyday life practices such as business activities and ethics, consumption patterns, and inter-personal relations.

\section{Conceptualising 'Islam' and 'Islamic Societies'}

Can we speak of Islam in the singular? Is there any one single universal definition of Islam? Can we assume that simply because people in different parts of the world follow Islam, they are similar in what they do and how they live? Do Muslims have the same perception of Islam and Islamic teachings? The answer to these questions is either 'yes' or 'no'.

\section{'YES'}

An affirmative answer to these questions is a grave mistake which treats Islam as a unanimous culture with homogenous collectivities and ignores all the historical socio-cultural values and beliefs that Islamic societies had traditionally lived by before embracing Islam (Jafari, 2009). This fallacy, as Al-Azmeh (2009, p. 80) tactfully reminds us, "takes place within the medium of variants of a discourse of 'authenticity', in which societies chosen as the field of application of the totalising category of 'Islam' - 'Islamic societies' - are thought to constitute a Lebenswelt with an essential and closed homogeneity". This assumption conceptualises religion as "a distinctive space of human practice and belief which cannot be reduced to any other [practice and belief]' (Asad, 1993, p.27). That is, religion is assumed to have an 'autonomous essence' which remains unchanged throughout history. This assumption indicates that the Islam people practise today is the Islam of fourteen centuries ago and statically will continue to remain so.

Such a 'transhistorical' (Asad, 1993; Al-Azmeh, 2009) assumption overlooks the historical development of Islam - as a set of socio-cultural and economic formations (Jafari et al., 2011) - and its experiences of enlightenment, internal and external conflicts, and change on its route to modernity. This approach is rooted in the projects of Orientalism and selfOrientalism. The historical project of Orientalism which had traditionally depicted the world of Islam based not on its own reality but on the imagination of the European missionaries travelling in Muslim territories (Said, 1978; Al-Azmeh, 2009) still prevails in contemporary discourses on Islam (Jafari and Süerdem, in press). That is, there has been a false divide between Islam (depicted predominantly as a political ideology) and the rest of the world (often the West as the flagship of modernity) (Pieterse, 1996). These assumptions juxtapose Islam as the 'other' of modernity and imply that the universal Islam continues to resist the globalising progressive socio-cultural and economic project of Western modernity (see Huntington, 1997). This unbalanced and ahistorical juxtaposition of Islam and the West is a 'pseudo-crusade' (Jafari et al., 2011). 
Whilst the project of Orientalism speaks of a single universal Islam and a homogenous Islamic community, the project of 'self-Orientalism' further strengthens this view. That is, Muslims fuel the project of Orientalism by alienating themselves as an Islamic 'Ummah', a collective nation of states. This collectivism is often associated with homogeneity. To clarify, I do not deny the existence of certain homogeneous characteristics (e.g., beliefs and practices) that prevail in the Muslim world, just as they do in any human society; the core of my argument is that homogeneity should not be oversimplified at the expense of historical trajectories that underpin contemporary Muslim societies' life conditions and practices. For instance, take the case of hejab (veiling) which shows the context-dependency and historicity of certain life practices in the Muslim world:

"The fact that women's hejab is so widely diverse in different Muslim societies is not simply a matter of women's own choice (as part of their religious/cultural practices) or geographical conditions (e.g., weather) of the contexts in which they live but is also related to the ways women have been historically defined, and are therefore expected to behave in certain ways, in those societies."

(Jafari and Süerdem, in press).

'NO'

There is also a negative answer to our questions regarding the nature of Islam and Islamic societies. From this perspective, Islam comes in different forms and interpretations. Muslims accumulatively believe that the sources of understanding Islam are the Holy Qur'an and Sunnah. Yet, the same sources are interpreted differently by different Muslims around the world. In their everyday life situations, Muslims (re)interpret religious guidelines in different ways and refer to Islam, as a transcendental set of guidelines, to make better sense of their socio-cultural and economic practices in different ways (Jafari and Süerdem, in press). In other words, they do not pursue a rigid 'rational logic' of religiosity; rather, they follow a 'practical logic' and act according to their 'feel for the game' of life (Bourdieu, 1977).

There is no single universal definition of Islam. As Asad (1993) forcefully argues, religion is historically defined. Since defining is a historical act, a universal conception of religion cannot exist. Definitions of religion are altered over time. Universal definitions of religion divert us from questions about what religion is, what it offers, and how it is enacted in the reality of everyday life. Likewise, our knowledge of religion is dynamic. For instance, whether we consider religion to be present in our public and/or private lives is a matter of historical construction of our knowledge of religion. Religion, as we see it today, is the result of discursive processes. That is, different institutions such as states and religious seminaries have influenced the way religion has been defined and empowered in society. In Asad's (1993, p.29) words:

"What we call religious power was differently distributed and had a different thrust. There were different ways in which it created and worked through legal institutions, different selves that it shaped and responded to, and different categories of knowledge which it authorised and made available."

A live example of this relationship between religion and power and knowledge is the multiplicity of 'Islams' and Islamic knowledge amongst Muslims. For all Muslims $\mathrm{Ka}$ 'bah is the Qiblah ${ }^{i i}$, and Mohammad (P.B.U.H.) is the Grand Prophet; yet, Muslims compete over their claims to authenticity of Islam. This kind of rivalry, at the micro level, is a matter of 
'Islam of identity' (Soroush, 2000). This authenticity is nothing more than the congruence between what Islam is meant to be (by God and mediated by the Prophet) and how it is understood. That is, Muslims use different forms of Islam to signal their cultural identity distinctions (Jafari and Süerdem, in press). For instance, hejab is very diverse in Islamic societies and the type of hejab indicates its geographical origin and socio-cultural orientation (e.g., Indonesia, Pakistan, Iran, Turkey, Iraq, Saudi Arabia). Interestingly, fuelled by ethnocentrism, Muslims may regard certain types of hejab as inappropriate, hence enforcing their own hegemonic preferences and distinctive identity discourses.

Moving to the macro level, such rivalry and hegemonic reflexivity is clearly fostered by states and Islamic seminaries in many Islamic countries (e.g., Saudi Arabia, Iran, Pakistan, Turkey). This means that to fulfil their geo-political and economic goals and sustain their cultural sovereignty and overall hegemonic discourses, states and religious authorities endeavour to produce, disseminate, and maintain their distinct prescriptions of Islam. The emergence of the concept of 'authentic Islam' in the contemporary discussions and discourses on Islam is an obvious indicator of the existence of power relations amongst different schools of thought (El Fadl, 2001).

Based on these premises, therefore, the notion of Islamic belief becomes problematic. A key question that arises before us is: how are religious beliefs enacted in everyday life situations? Religious beliefs are not static; they are shaped and altered by the incoming knowledge, or the changing landscape, of religion. Beliefs may or may not be enacted as practices. As Warde (2005) and Schatzki (1996) propose, practices (e.g., social, cultural, economic) are performed qualities of individuals, things such as beliefs and knowledge. Such beliefs and knowledge are enacted in the form of life practices based on their historically influenced situatedness. As Jafari and Süerdem (in press) maintain, "if Islam is dealt with as identity, Muslims may define their religiosity in contrast with two major groups: non-Muslims and Muslims from other sects and geographical contexts." These identity differences and cultural distinctions manifest themselves in worldly and/or mundane socio-cultural and economic practices such as consumption culture, lifestyle choices, economic behaviours, work habits, business patterns and ethics, and so forth. Conversely, if Islam is perceived as a 'repository of truths' (Soroush, 2000), individuals will organise their lives to embrace the 'truth' from their own perspective which may differ from others' 'truths' (Jafari and Süerdem, in press). This means that their Islamic beliefs and knowledge may be enacted in different forms of practices, even within the boundaries of the same apparently homogeneous society.

\section{Islam as a Tool or a Resource?}

It is wrong to assume that Islam can be rendered as a marketing tool. Such a reductionist view oversimplifies both Islam and marketing. This assumption narrows Islam to the limited boundaries of marketing which is only one, out of many, of the institutions that shape markets as 'social constructions' (Peñaloza and Venkatesh, 2006; Araujo, 2007; Tadajewski, 2010). Islam is not a tool; it is a resource. Religion is one of the many resources that influence and shape market practices and market-making activities such as marketing (Jafari, 2010). In its denotative meaning, a resource is a limited entity, but what can extend the lifespan of a resource is the way that resource is utilised and dealt with. If handled in a 
reductionist manner, Islam will be a finite resource with an expiry date. This happens when Islamic traditions are looked upon as a set of static tenets.

An example of this reductionism, as Jafari and Süerdem (in press) and Jafari et al. (2011) criticise, is monotonously confining Islam within the rigid boundaries of Halal (the lawful) and Haram (the unlawful), the Mustahabb (favoured) and Makruh (disliked), and punishment (fear of God) and reward (zest for the Paradise) as the main motivations which drive Muslims' deeds and decision making processes. Such terms as Halal and Haram which are generally oversimplified, misunderstood, and misrepresented in the marketing literature (Alserhan, 2010; Wilson and Liu, 2010) are complex concepts that need to be analysed in relation to more complicated issues such as identity discourses, political and ideological dynamics, consumer agency and resistance, and the changing landscape of religion. Confining Islam within these inflexible margins is destructive. Such narrow references to the Islamic traditions - which are time-bound and context-bound - will not add much to our existing knowledge of Islam. Even more, sticking to these concepts - that are increasingly becoming problematic in the reality of everyday life - will only deprive us of understanding a bulk of complicated matters that are emerging in different areas of social life. For instance, as Jafari and Süerdem (in press) argue, in the phase of a globalising consumer culture, reliance on conventional readings of Islam will not help to understand a wide range of paradoxical consumption practices amongst Muslims.

On the other hand, if treated meticulously, Islam will remain a renewable resource. If so, Islam will be able to renew its dynamic socio-cultural and economic agenda. However, the renewal of this resource largely depends on how we make sense of the religion in an everchanging world. Our knowledge of Islam, therefore, needs to be dynamic and, in the light of reflexive understanding of the world around us, evolve over time.

\section{A Shift from Sacralisation towards a Critical Perspective}

Critique is a key element of the advancement of knowledge. Critique questions taken-forgranted assumptions, problematises understatements and overstatements, generates further ideas, establishes dialogues, and fosters reflexivity. It is an invaluable conduct which seeks clarifications of ontological, epistemological, and methodological positions and procedures. JIMA contributors need to practise this scholarly tradition in all matters. A starting point for fulfilling this objective is to abandon dogmatic conceptualisations of Islam as a sacralised religion. As mentioned earlier in this paper, in my view, in our analysis of Islamic traditions, we do not need to be apologetic. Our task is not, therefore, to interpret Islam from a theological perspective. On the contrary, we should embark on investigating how people's interpretations of Islam, in the long term, influence their various market related activities and practices. This does not require any metaphysical surgery of Islam in order to prove that the religion is sacred. As agreed amongst Muslims, Islam is a 'transcendental reality' (Jafari and Süerdem, in press), which stands above the reality of society - unlike Durkheim's (1984/1893) conceptualisation of religion as a socially constructed phenomenon - and it is people's enactment of their religiosity that makes Islam tangibly present in everyday life situations.

Amongst Muslim scholars, it is a common mistake to remain apologetic in their confrontation vis-à-vis the non-Muslim world. That is, the majority of Muslim writers defend Islam based on their understanding of religion and critique non-Islamic ideas, values, and practices. Yet, ironically they fail to critique their own ideas, values, and practices which 
have been, in the long term, institutionalised in their socio-cultural settings. As Hashim (1964, p. 36) contends, the progression of knowledge in the world of Islam requires Muslim scholars to reflexively critique their past knowledge. This lack of reflexivity and critique is a main drawback of Islamic scholarship.

Typically, the majority of Muslim thinkers sacralise Islam with the hope of serving the religion, but fail to understand that this sacralisation of religion hampers reflexivity, flexibility, self-examination, and self-critique (Sanei Darrehbidi, 1998). For instance, a glance at Islamic philosophy provides evidence for the fact that, compared to Western philosophy, Islamic philosophy has been less progressive ${ }^{\mathrm{iii}}$. This is the direct outcome of the lack of critique and reflexivity (Mojtahed Shabestari, 1996, 2000; Akhtar, 1997). Since Islamic scholarship is founded on the premises of Towhid (oneness of God) and unity (Nasr, 2003; Akgül, 1997), the development of philosophy among Muslims has experienced a linear process. The Towhid-based philosophy has been married into a sacralised religion as a result of which philosophy itself has been sacralised. Such a perspective is neither truly Islamic (because Islam accentuates rationalism) nor truly philosophic (because philosophy's mission is to rationally discover the nature of the universe) (Sanei Darrehbidi, 1998). This metaphysics-oriented philosophy has, to this very date, dominated humanities and social sciences in Islamic societies. An immediate consequence of this inauspicious heritage is that Islamic scholarship looks backward (Sanei Darrehbidi, 1998). That is, instead of examining contemporary phenomena (e.g., consumption culture, the paradoxes of market developments, and identity conflicts) in innovative ways, such phenomena are either instantly negated (e.g., the rapid growth of consumer culture as part of cultural Imperialism) or monotonously described with reference to the traditional dogmatic frameworks (e.g., Halal/Haram). It is only through engagement with critique that Muslim writers can transgress the boundaries of the knowledge they have inherited from their predecessors. Extending this discussion to marketing will offer a series of implications:

Firstly, as a result of practising reflexivity and self-critique, Muslim scholars will not be entrapped in vicious circles of ideas (e.g., Halal/Haram, punishment/reward dichotomies). As Jafari and Süerdem (in press) stress, theory development in the realm of marketing in Islamic societies requires scholars researching and working in these contexts to conduct empirical research in order to investigate Muslims' multiple engagements with markets (e.g., consumption practices, ethics, marketing activities, etc.). Understanding these phenomena necessitates the application of inductive methods. Otherwise, heavy reliance on deductive approaches (particularly, testing the theories that have been developed in non-Muslim contexts) will not contribute much to our understanding of different marketing phenomena in these societies. Similarly, a better understanding of these phenomena will be achieved through embracing multiple understandings of Islam in a hermeneutic manner (Jafari et al., 2011).

Secondly, self-critique and reflexivity will save Muslim researchers from falling into the well of self-fascination. The majority of misunderstandings in the field of marketing are rooted in 'historical amnesia' (Tadajewski and Saren, 2008) and 'ahistorical' approaches to marketing (Tadajewski, 2009). Historically, it is true that Muslims' interpretations of Islam in the Islamic Golden Age $\left(7^{\text {th }}-13^{\text {th }}\right.$ centuries) played a significant role in the development of markets in Islamic territories, but one should also acknowledge the fact that the pre-Islam societies (e.g., the Arabian Peninsula and Persia) had, by then, developed their own relatively sophisticated markets and market-making practices (Labib, 1969; Baek, 1991; Silver, 1983; Jafari, 2010). Therefore, in their consideration of marketing phenomena, JIMA scholars are 
invited to broaden their analytical lens to avoid ahistorical myopia. History has witnessed a great deal of contributions from non-Muslims who have influenced the structures and contents of the markets we are all involved in today. For instance, one cannot ignore Adam Smith's (1776) 'Wealth of Nations' in contemporary discussions on markets and civil society.

Thirdly, self-critique and reflexivity will help scholars to investigate marketing phenomena in the broader context of the social reality of life. Like many other societies, Muslims are experiencing a number of issues such as poverty and injustice (Dusuki, 2008; Al-Roubaie, 2009; Sardar, 1997; Üstüner and Holt, 2007), unethical practices (Tsalikis and Lassar, 2009; Abdullah and Ahmad, 2010), discrimination (Mojab, 2001; Sidani, 2005; Syed, 2008), ideological conflicts (Jafari and Goulding, 2008, 2010, in press; Jafari et al., 2010), identity awareness (Sandikci and Ger, 2002, 2007, 2010; Jafari and Goulding, in press), and environmental challenges (Rice, 1999; Salehi, 2010; Awad, 2011), to name but a few. Marketing scholars in Islamic societies can make significant contributions to the field by addressing these issues that are of significance to not only Muslim societies but also human society at large.

There is an established and fast growing body of knowledge in marketing which addresses these highly important topics. This stream of research conceptualises markets as social constructions (Peñaloza and Venkatesh, 2006; Araujo, 2007; Collins, 1990; Tadajewski, 2010; García-Rosell et al., 2007). From this perspective, there are multiple actors in the markets, where political and ideological regimes, economic and technological infrastructure, socio-cultural systems, marketers and consumers interactively influence the contents as well as structures of markets. Such conceptualisations of markets have fundamentally questioned the taken-for-granted assumptions about how markets come in to existence, evolve over time, and interact with other social institutions that eventually influence human lives at large. The emergence of critical studies, both from within and out with the marketing discipline, has particularly played an important role in the growth of selfcritique of marketing (Tadajewski, 2010; Burton, 2001; Peñaloza and Venkatesh, 2006; Tadajewski and Brownlie, 2008). Such a critical perspective seeks to embed the marketcentred worldview within the broader context of the society-centred worldview (Peñaloza and Venkatesh, 2006), one that would liberate marketing from its micro environment (e.g., managerial implications) and re-establish it in society as its macro habitat (Firat and Dholakia, 1997; Tadajewski, 2010). For instance, as Firat and Dholakia (1998) and Firat (1999) forcefully remind us, people do not live in, or for, the market. A majority of people engage with markets and use marketplace resources to organise their lives and fulfil their life projects in their social settings (Peñaloza and Venkatesh, 2006; Tadajewski, 2010). These critical perspectives in humanistic marketing can open up many avenues for JIMA authors for engagement with topics that are both relevant and important to contemporary life conditions in Islamic societies. As a result, authors will be able to discover the potentials of Islam as a resource that can help more just, ethical, and humanistic market and marketing activities.

\section{Conclusion}

My key objective in this article has been to highlight the importance of reflexivity and selfcritique to the development of knowledge in the domain of Islamic marketing. Within the space constraints of the manuscript, I identified and discussed three key issues that I regard as drawbacks of the discussions so far put forward in JIMA. First, I argued that in our analysis of marketing phenomena in the context of Islam or Islamic societies, we need to adopt a 
pluralistic approach which acknowledges multiplicity of Islams and Islamic interpretations. Then, I emphasised that Islam is a resource (not a tool) and our ability of extending the lifespan of this resource lies in our ability of making sense of Islam and extending our knowledge of the religion. Thirdly, I stressed that sacralisation of Islam is a dangerous act, which will inevitably deprive us of the fruits of critique and reflexivity.

Here, I want to emphasise that Islam does indeed promote humanistic ways of living including humanistic business philosophy and practice. Yet, this is not an exclusive characteristic of Islam. There is a rapidly growing body of knowledge out there that promotes humanistic marketing and management practice. Scholars targeting JIMA are humbly invited to engage with this stream of research (namely critical perspective in marketing). This way, the marketing literature will be enriched by more exciting phenomena that are of more relevance and significance to the conditions of contemporary life in Muslim contexts. JIMA articles should not simply focus on providing international firms with market and marketing information about Islamic contexts and then inviting them on how to enter a given market. A key area that the Journal can contribute to is humanistic marketing as explained above.

Humanistic marketing agenda are extremely relevant to the rapidly changing conditions of people living in Islamic societies and Muslims all around the world. For instance, the recent political uprisings in the Arab world (e.g., Tunisia, Egypt, Libya, Syria, Yemen, and Bahrain) are deeply rooted in people's yearning for better life conditions and socio-economic justice as well as political reforms and social change. As highlighted by 'The Economic Freedom of the Arab World Conference 2009 Report', the lack of synergy between economic liberalisation and political reforms has, during the past few decades, deeply institutionalised cronyism and lack of transparency in these countries. Consequently, diverse economic activities and business practices have not only not created equal opportunities for people to participate in and enjoy market developments, but also intensified socio-economic injustice (e.g., unemployment, poverty, and unequal access to marketplace resources). Given the changing political climate in these countries, it is imperative to understand how markets and marketing (as a market-making resource) are likely to be affected by, and affect, socioeconomic development processes in these societies.

Although both Muslim and non-Muslim scholars are invited to address these timely issues, there are certain areas of inquiry (e.g., Haram/Halal dichotomies, consumption paradoxes, Islam as culture) where Muslim scholars' timely engagement with the topics under question will shed more light on the ambiguities that have haunted the literature on 'Islamic' related issues. The main reason for this, as Alserhan $(2010, \mathrm{p} .105)$ indicates, is that "living Islam and having some knowledge about it" are two different things.

\section{References}

Abdullah, K. And Ahmad, M.I. (2010), "Compliance to Islamic Marketing Practices among Businesses in Malaysia", Journal of Islamic Marketing, Vol. 1 No. 3, pp. 286-297.

Akgül, M. (1997), "Science and Civilisation in Islam", Ilahiyat Dergisi (Review of the Faculty of Divinity, Selçuk University), No. 7, pp. 359-368.

Akhtar, S.W. (1997), "The Islamic Concept of Knowledge”, Al-Tawhid: A Quarterly Journal of Islamic Thought \& Culture, Vol. 12 No. 3. Available at http://www.al-islam.org/altawhid/islam-know-conc.htm (accessed 1 April 2011). 
Al-Azmeh, A. (2003), "Postmodern Obscurantism and 'the Muslim Question"”, Journal for the Study of Religions and Ideologies, Vo. 2 No. 5, pp. 21-47.

Al-Azmeh, A. (2009), Islam and Modernities, Verso, London.

Alserhan, B.A. (2010), “On Islamic branding: brands as good deeds", Journal of Islamic Marketing, Vol. 1 No. 2, pp. 101-106.

Al-Roubaie, A. (2009), "Islamic Economics: An Approach to Development Alternatives in Muslim Societies", in Marcinkowski, C. (Ed.), The Islamic world and the West: managing religious and cultural identities, Lit Verlag, Berlin.

Araujo, L. (2007), "Markets, market-making and marketing”, Marketing Theory, Vol. 7 No. 3, pp. 211-226.

Asad, T. (1993), "The Construction of Religion as an Anthropological Category", in Asad, T. (Ed.), Genealogies of Religion: Discipline and Reasons of Power in Christianity and Islam, Johns Hopkins University Press, Baltimore, MD.

Awad, T.A. (2011), “Environmental segmentation alternatives: buyers' profiles and implications", Journal of Islamic Marketing, Vol. 2 No. 1, pp. 55-73.

Baeck, L. (1991), “The Economic Thought of Classical Islam”, Diogenes, No. 154, pp. 99116.

Bourdieu, P. (1977/1972), Outline of a Theory of Practice, Nice, R. (Trans.), Cambridge University Press, Cambridge.

Burton, D. (2001), "Critical marketing theory: the blueprint?", European Journal of Marketing, Vol. 35 No. 5/6, pp. 722-743.

Collins, R. (1990), "Market Dynamics as the Engine of Historical Change", Sociological Theory, Vol. 8 No. 2, pp. 111-35.

Durkheim, E. (1984/1893), The Division of Labor in Society. Halls, W.D. (Trans.), Basic Books, New York, NY.

Dusuki, A.W. (2008), "Understanding the objectives of Islamic banking: a survey of stakeholders' perspectives", International Journal of Islamic and Middle Eastern Finance and Management, Vol. 1 No. 2, pp. 132-148.

El Fadl, K.A. (2001), "Islam and the Theology of Power", Middle East Report, No. 221 (winter), pp. 28-33.

Frrat, A. F. (1999), "Rethinking Consumption”, Consumption Markets \& Culture, Vol. 3 No. 4, pp. 283-96.

Firat, A.F. and Dholakia, N. (1997), "Consumption Patterns and Macromarketing: a radical perspective", European Journal of Marketing, Vol. 11 No. 4, pp. 291-98.

Firat, A.F. and Dholakia, N. (1998), From Political Economy to Theatres of Consumption, Routledge, London. 
García-Rosell, J.C., Haanpää, M., Kylänen, M. and Markuksela, V. (2007), "From firms to extended markets: A cultural approach to tourism product development", Tourism Review, Vol. 55 No. 4, pp. 445-59.

Hashim, A. (1964), "The Creed of Islam and the World of Today", The Islamic Review, No. 52 (Dec.), pp. 33-36.

Huntington, S. (1997), The Clash of Civilisations: remaking of world order, Touchstone, New York, NY.

Jafari, A. (2009), "Misconceptions of Culture in Cross-cultural Business and Management Studies", International Journal of Management Concepts and Philosophy, Vol. 3 No. 4, pp. 349-61.

Jafari, A. (2010), "A Historical Review of the (Re)Formation of Markets in the Context of Islamic Capitalism (7th -13th Centuries)", paper presented at the 1st Interdisciplinary Market Studies Workshop, Stockholm School of Economics, June.

Jafari, A., \& Goulding, C. (2008), “'We are not terrorists!' UK-based Iranians, consumption practices and the 'torn self'", Consumption, Markets and Culture, Vol. 11 No. 2, pp. 7391.

Jafari, A. and Goulding, C. (2010), "Globalisation Tug-of-War: Consumption as a Site of Conflict", Advances in Consumer Research, Vol. 38 No. 1, First published in 2010 (iFirst).

Jafari, A. and Goulding, C. (in press), "Globalization, Reflexivity and the Project of the Self: A Virtual Intercultural Learning Process", Consumption, Markets, and Culture.

Jafari, A. Karababa, E., and Süerdem, A. (2011), "Emancipatory Interpretive Consumer Research: "The Road Less Travelled By" in Islamic Societies", Paper presented at the 6th Workshop on Interpretive Consumer Research, Southern University of Denmark, Odense.

Jafari, A., Maclaran, P. and Taheri, B. (2010), "The Flow of Cosmetic Routines in Iran. Advances in Consumer Research, Vol. 38 No. 1, First published in 2010 (iFirst).

Jafari, A. and Süerdem, A. (in press), "An Analysis of Material Consumption Culture in the Muslim World", Marketing Theory.

Labib, S.Y. (1969), “Capitalism in Medieval Islam”, The Journal of Economic History, Vol. 29 No. 1, pp. 79-96.

Mojab, S. (2001), "Theorising the Politics of "Islamic Feminism”, Feminist Review, Vol. 69 No. 1, pp. 124-146.

Mojtahed Shabestari, M. (1996), Hermenutik, Kitab va Sunnat [Hermeneutics, the Book and Tradition], Tarh-e Now, Tehran. (in Farsi)

Mojtahed Shabestari, M. (2000), Naqdi bar Qira'at-e Rasmi-e Din [A Critique of the Official Reading of Religion], Tarh-e Now, Tehran. (in Farsi)

Nasr, S.H. (2003), Science and Civilisation in Islam (2 ${ }^{\text {nd }}$ Ed.), Islamic Texts Society, London. 
Peñaloza, L. and Venkatesh, A. (2006), "Further evolving the new dominant logic of marketing: from services to the social construction of markets", Marketing Theory, Vol. 6 No. 3, pp. 299-316.

Pieterse, J.N. (1996), "A Severe Case of Dichotomic Thinking: Bassam Tibi on Islamic Fundamentalism”, Theory, Culture \& Society, Vol. 13 No. 4, pp. 123-26.

Rice, G. (1999), "Islamic Ethics and the Implications for Business", Journal of Business Ethics, Vol. 18 No. 4, pp. 345-358.

Said, E. (1978), Orientalism, Vintage Books Edition, London.

Salehi, S. (2010), Pepole and the Environment: A Study of Environmental Attitudes and Behaviour in Iran, Lambert, Germany.

Sandikci, O. and Ger, G. (2002), "In-Between Modernities and Postmodernities: Theorising Turkish Consumptionscape”, Advances in Consumer Research, Vol. 29 No. 1, pp. 465-70.

Sandikci, O. and Ger, G. (2007), "Constructing and Representing the Islamic Consumer in Turkey", Fashion Theory, Vol. 11 No. 2/3, pp. 189-210.

Sandikci, O. and Ger, G. (2010), "Veiling in Style: How Does a Stigmatised Practice Become Fashionable", Journal of Consumer Research, Vol. 37 No. 1, pp. 15-36.

Sanei Darrehbidi, M. (1998), "Negaresh-e enteghadi bar ravesh-e tahghigh va tafakkor dar falsafeye eslami" (a critical analysis of methodology and thinking in Islamic philosophy), Mofid, No. 15 (Autumn), pp. 4-20.

Sardar, Z. (1997), "Beyond development: An Islamic perspective", in Tucker, V. (Ed.), Cultural perspectives on development. Frank Cass, London.

Schatzki, T. (1996), Social Practices: A Wittgensteinian Approach to Human Activity and the Social, Cambridge University Press, Cambridge.

Sidani, Y. (2005), "Women, work, and Islam in Arab societies", Women in Management Review, Vol. 20 No. 7, pp. 498-512.

Silver, M. (1983), "Karl Polanyi and Markets in the Ancient Near East: The Challenge of the Evidence”, Journal of Economic History, Vol. 43, pp. 795-829.

Smith, A. (1776), An Inquiry into the Nature and Causes of the Wealth of Nations, Starhan and Cadell, London.

Soroush, A. (2000), Reason, Freedom, and Democracy in Islam, Sadri, M. and Sadri, A. (Eds.), Oxford University Press, Oxford.

Syed, J. (2008), "A context-specific perspective of equal employment opportunity in Islamic societies”, Asia Pacific Journal of Management, Vol. 25 No. 1, pp. 135-151.

Tadajewski, M. (2009), "Editing the History of Marketing Thought", Journal of Historical Research in Marketing, Vol. 1 No. (2), pp. 319-329.

Tadajewski, M. (2010), "Towards a history of critical marketing studies", Journal of Marketing Management, Vol. 26 No. 9/10, pp. 773-824. 
Tadajewski, M. and Brownlie, D. (2008), "Critical marketing: A limit attitude", in Tadajewski, M. and Brownlie, D. (Eds.), Critical marketing: Issues in contemporary marketing. Wiley, Chichester.

Tadajewski, M. and Saren, M. (2008), "The past is a foreign country: amnesia and marketing theory", Marketing Theory, Vol. 8 No. 4, pp. 323-38.

The Economic Freedom of the Arab World Conference 2009 Report. Available at http://www.freetheworld.com/arab/Arabic_Economic_Freedom_2009.pdf (accessed 28 March 2011).

Tsalikis, J. and Lassar, W. (2009), "Measuring Consumer Perceptions of Business Ethical Behavior in Two Muslim Countries", Journal of Business Ethics, Vol. 89 No. 1, pp. 9198.

Üstüner, T. and Holt, D.B. (2007), "Dominated Consumer Acculturation: The Social Construction of Poor Migrant Women's Consumer Identity Projects in a Turkish Squatter", Journal of Consumer Research, Vol. 34 No. 1, pp. 41-56.

Warde, A. (2005), "Consumption and Theories of Practice", Journal of Consumer Culture, Vol. 5 No. 2, pp. 131-53.

Wilson, J. and Liu, J. (2010), "Shaping the Halal into a Brand", Journal of Islamic Marketing, Vol. 1 No. 2, pp. 107-123.

Notes:

\footnotetext{
${ }^{\mathrm{i}}$ The Holy Shrine in Masjid Al-Haram

ii The direction that should be faced when a Muslim prays

iii Akhtar (1997) tactfully argues that the stagnation and decline of Islamic philosophy and scientific thinking, along other historical and social circumstances, is the result of the fact that Muslims "confined themselves to theology as the only obligatory knowledge" and abandoned critical thinking.
} 